\title{
Pengukuran Dividend Payout Ratio Melalui Return On Assets dan Earning Per Share
}

\author{
Listia Andani \\ Program Magister Ekonomi Islam UIN Sunan Gunung Djati Bandung \\ Corresponding Author Email: listiaandani@gmail.com
}

\begin{abstract}
This study was conducted to determine the effect of the independent variable Return On Assets (ROA) and Earning Per Share (EPS) partially and simultaneously on the dependent variable Dividend Payout Ratio (DPR). PT. PP London Sumatra Indonesia Tbk., One of the companies listed on the Jakarta Islamic Index (JII), was used as a research site for the period 2009-2017. This research was processed by descriptive quantitative approach method as well as descriptive analysis techniques and multiple linear test techniques. The results of the study concluded that simultaneous Return On Assets (ROA) and Earning Per Share (EPS) had a positive and significant effect on Dividend Payout Ratio (DPR), as evidenced by the comparison between the Fcount and Ftable values of $6.361>5.14$ with a significance of $0.033<0.05$. The next results, namely the magnitude of the influence of the variable Return On Assets (ROA) and Earning Per Share (EPS) on the variable Dividend Payout Ratio (DPR) is $68 \%$. Meanwhile, for $32 \%$ the level of the variable Dividend Payout Ratio (DPR) is influenced by other variables not examined.
\end{abstract}

Keywords: Dividend Payout Ratio, Earning Per Share, Return On Assets

\begin{abstract}
ABSTRAK
Penelitian ini dilakukan untuk mengetahui pengaruh variabel independen Return On Assets (ROA) dan Earning Per Share (EPS) secara parsial dan simultan terhadap variabel dependen Dividend Payout Ratio (DPR). PT. PP London Sumatra Indonesia Tbk., salah satu perusahaan yang terdaftar di Jakarta Islamic Index (JII), digunakan sebagai tempat penelitian dengan periode 2009-2017. Penelitian ini diolah dengan metode deskriptif pendekatan kuantitatif serta teknik analisis deskriptif dan teknik uji linier berganda. Hasil penelitian menyimpulkan bahwa secara simultan, Return On Assets (ROA) dan Earning Per Share (EPS) memiliki pengaruh positif dan signifikan terhadap Dividend Payout Ratio (DPR), dibuktikan dengan perbandingan antara nilai Fhitung dan Ftabel sebesar $6.361>5.14$ dengan signifikansi $0.033<0.05$. Hasil selanjutnya, yaitu besaran pengaruh variabel Return On Assets (ROA) dan Earning Per Share (EPS) terhadap variabel Dividend Payout Ratio (DPR) adalah 68\%. Sedangkan, untuk 32\% tingkat variabel Dividend Payout Ratio (DPR) dipengaruhi oleh variabel lain yang tidak diteliti.
\end{abstract}

Kata kunci: Pengembalian Aset, Penghasilan Per Saham, Rasio Pembayaran Dividen

\section{PENDAHULUAN}

Di era yang semakin modern ini, seorang muslim dituntut memiliki cara pandang yang luas dan pantas agar dapat mengikuti tren hidup yang semakin berkembang namun masih berpijak pada koridor syariah yang seharusnya (Santoso \& Ulfah, 2016). Kehidupan umat muslim sehari-hari tentunya tidak akan terlepas dari kegiatan ekonomi yang biasa dilakukan (Huda, 2018). Sebagai muslim yang taat, maka sudah sewajarnya jika dituntut untuk tetap berkegiatan namun berlandaskan prinsip-prinsip syariah yang sesuai dengan tuntunan yang tertuang dalam al quran dan hadis. Investasi merupakan salah satu kegiatan ekonomi yang biasa dilakukan oleh umat muslim. Hal ini tentunya harus dilakukan berlandaskan hukum

* Copyright (c) 2020 Listia Andani

This work is licensed under a Creative Commons Attribution-ShareAlike 4.0 International License.

Diterima: 29 Februari 2020; Direvisi: 7 November 2020 ; Disetujui: 8 November 2020 
Khazanah Sosial, Vol. 2 No. 3: 205-216

Pengukuran Dividend Payout Ratio Melalui Return on Assets Dan Earning Per Share Listia Andani

Islam yang berl (Huda, 2018)aku, dimana kegiatan investasi tersebut haruslah menjunjung tinggi prinsip syariah dengan segala aspek yang berkaitan di dalamnya juga tidak boleh melanggar prinsip agama yang telah ditetapkan.

Investasi adalah cara bagi seseorang, atau biasa disebut investor, yang ingin memanfaatkan modal yang dimiliki demi memperoleh keuntungan di masa depan (Fahmi, 2006). Hal ini juga senada dengan yang dianjurkan kepada umat muslim agar memanfaatkan hartanya sebaik mungkin demi kebaikan di masa mendatang. Dengan berinvestasi, seseorang diharapkan memiliki komitmen terhadap hartanya dan dapat memanfaatkannya pada sebuah media yang tepat dengan memperhatikan norma-norma syariah yang akan melabelilasi kehalalannya. Harta yang diinvestasikan selanjutnya dialokasikan dengan pertimbangan yang matang, sehingga harta yang telah ditanamkan saat ini tersebut nantinya diharapkan akan lebih berguna untuk kehidupannya di masa mendatang.

Pemanfaatan harta dengan cara investasi dapat dilakukan dengan berbagai cara asalkan tidak menabrak koridor syariah yang telah ditetapkan. Belakangan ini, alternatif investasi yang diminati serta mulai berkembang di Indonesia saat ini dari tahun ke tahun adalah investasi portofolio yang merupakan jenis investasi tidak langsung. Investasi portofolio merupakan jenis investasi tidak langsung yang mengklaim aset-aset dengan surat berharga atau yang biasa disebut dengan securities (Prasetyo, 2017). Investasi portofolio yang dikenal secara luas merupakan cara investasi dengan membeli saham oleh perusahaan atau yang biasa disebut dengan emiten go public yang diterbitkan di pasar modal.

Belakangan ini, para investor khususnya investor muslim yang akan menanamkan dananya mulai tertarik pada pasar modal syariah untuk kegiatan berinvestasinya. Hal ini berkaitan dengan daftar saham yang berada di pasar modal syariah merupakan nama saham dari perusahaan yang telah mengalami filter khusus. Penyaringan terhadap perusahaan yang ingin memasuki pasar modal syariah ini dilakukan dengan kriteria-kriteria tertentu sehingga selanjutnya akan digolongkan sebagai saham syariah yang dapat dipilih investor. Sehingga, pasar modal syariah ini akan aman digunakan oleh umat muslim untuk berinvestasi (Syairozi \& Cahya, 2017).

Jakarta Islamic Index (JII) merupakan indeks yang memandu investor untuk menanamkan dananya berdasarkan prinsip syariah. Indeks ini berisi perusahaan-perusahaan yang sudah tersaring menurut kriteria tertentu dan dikategorikan sebagai saham syariah (Huda \& Heykal, 2010). Jakarta Islamic Index (JII) dianggap sebagai indeks yang valid karena berisi tiga puluh nama besar dari perusahaan paling likuid yang tergolong dalam saham syariah. Setiap dua kali dalam setahun, indeks ini melakukan penyaringan sehingga daftar nama perusahaan yang ada dalam indeks ini selalu valid dan dapat menjadi pertimbangan investor dalam keputusannya. Salah satu nama perusahaan besar yang terdaftar konsisten dalam indeks Jakarta Islamic Index (JII) sejak periode Juli-Desember 2004 dengan kode saham LSIP adalah PT. PP London Sumatera Indonesia Tbk.

Penanaman investasi dengan menggunakan instrumen saham di pasar modal akan menimbulkan keuntungan bagi investor sebagai pemilik saham. Salah satu keuntungan investor dari penanaman dananya yaitu memperoleh dividen. Secara sederhana, dividen dapat dipahami sebagai bagian laba yang dibagikan kepada investor atau pemegang saham dari hasil keuntungan perusahaan setelah disetujui oleh pihak-pihak terkait dalam Rapat Umum Pemegang Saham (RUPS). Kebijakan pembagian besaran dividen suatu perusahaan akan tergambar dalam rasio pembayaran dividen atau yang biasa disebut dengan Dividend Payout Ratio (DPR). Rasio ini merupakan persentase keuntungan yang dibagikan dalam bentuk dividen tunai kepada investor (Parera, 2016).

Kebijakan dividen perusahaan ini tentunya dipengaruhi oleh beberapa faktor, di antaranya yang dinilai dominan dalam mempengaruhi besaran pembagian dividen adalah tingkat profitabilitas 
Khazanah Sosial, Vol. 2 No. 3: 205-216

Pengukuran Dividend Payout Ratio Melalui Return on Assets Dan Earning Per Share Listia Andani

perusahaan. Tingkat profitabilitas biasanya digunakan sebagai tolak ukur oleh investor dalam menganalisa serta menilai tingkat operasional perusahaan yang akan dijadikan sasaran investasinya. Rasio profitabilitas ini selanjutnya akan digunakan untuk menakar sejauh mana kemampuan perusahaan untuk menghasilkan keuntungan yang didapat dari kegiatan operasionalnya (Suardana, 2018). Rasio profitabilitas juga tentunya akan mempengaruhi tingkat besaran dividen yang diperoleh investor, karena dividen merupakan bagian dari keuntungan bersih perusahaan.

Pengukuran tingkat rasio profitabilitas ini selanjutnya akan menggambarkan kondisi perusahaan yang akan dipilih oleh investor dan menjadi nilai pertimbangan tersendiri dalam keputusan investasinya. Angka yang stabil dan cenderung mengalami peningkatan dari tahun ke tahun pada rasio profitabilitas biasanya yang dipilih oleh investor sebagai tempat investasinya. Hal ini dikarenakan investor menilai tingkat operasional perusahaan akan berbanding lurus dengan tingkat profitabilitasnya, yang artinya semakin tinggi nilai keuntungan suatu perusahaan, maka perusahaan tersebut selanjutnya akan dinilai memiliki performa kinerja operasional yang baik pula (Riyadi, 2017).

Salah satu rasio yang dapat menilai atau mengukur tingkat profitabilitas suatu perusahaan adalah rasio Return On Assets (ROA) (Kamal, 2018). Rasio ini merupakan rasio keuangan yang digunakan dengan tujuan untuk menilai tingkat keuntungan bersih yang dihasilkan perusahaan dan keuntungan tersebut diperoleh dari keseluruhan penggunaan aset perusahaan. Rasio ini menakar sisi efisiensi perusahaan dalam penggunaan aset secara keseluruhan dalam kegiatan operasionalnya yang selanjutnya akan menghasilkan keuntungan bersih (Syamsuddin, 2011). Produktivitas perusahaan dapat dilihat dan diukur dengan melihat besaran rasio Return On Assets (ROA), karena rasio ini dianggap berbanding lurus dengan tingkat produktivitas perusahaan (Satria, 2016).

Selain rasio Return On Assets (ROA), tingkat rasio Earning Per Share (EPS) juga merupakan hal mendasar lain yang menjadi pertimbangan investor dalam menanamkan sejumlah dana yang dimilikinya pada perusahaan. Jika Return On Assets (ROA) menakar besaran keuntungan bersih dari penggunaan keseluruhan aset, maka Earning Per Share (EPS) adalah rasio keuangan yang bertujuan untuk menakar besaran keuntungan bersih yang didapat perusahaan dari jumlah saham yang beredar di pasar. Informasi terkait besaran tingkat Earning Per Share (EPS) ini biasanya digunakan oleh para investor untuk menilai sejauh mana tingkat keuntungan perusahaan dan prospek pembagian dividen yang akan didapat dari menanamkan modalnya dalam perusahaan.

Jadi, baik rasio Return On Assets (ROA) maupun Earning Per Share (EPS) tingkatannya dinilai berbanding lurus dengan tingkat pembagian dividen yang akan diterima investor dan tergambar dalam angka Dividend Payout Ratio (DPR). Semakin tinggi tingkat rasio profitabilitas yang diukur dari penggunaan aset perusahaan serta jumlah saham yang beredar, maka semakin baik pula citra serta produktivitas perusahaan tersebut di mata investor. Selanjutnya, daya tarik perusahaan tersebut akan meningkat dikarenakan tingkat keuntungan atau pengembalian atas investasinya yang berupa dividen akan semakin besar pula (Darsono \& Ashari, 2005).

Senada dengan landasan penelitian yang telah digambarkan pada teori tersebut, maka peneliti juga menemukan beberapa penelitian sebelumnya yang mendukung keterkaitan antara data dan fakta hasil penelitian. Penelitian sebelumnya yang berkaitan tersebut di antaranya adalah penelitian dari Janifairus, dkk. (2013), Perpatih (2016), serta Wahyuni \& Hafiz (2018). Ketiga penelitian itu menghasilkan kesimpulan bahwa variabel independen Return On Assets (ROA) berpengaruh positif dan signifikan terhadap variabel dependen Dividend Payout Ratio (DPR). Selain ketiga penelitian tersebut yang menerangkan variabel Return On Assets (ROA), maka penelitian lain yang mendukung variabel Earning Per Share (EPS) yang dilakukan oleh Pratama (2015) dan Sarmento (2016) juga menghasilkan kesimpulan 
Khazanah Sosial, Vol. 2 No. 3: 205-216

Pengukuran Dividend Payout Ratio Melalui Return on Assets Dan Earning Per Share Listia Andani

bahwa variabel independen Earning Per Share (EPS) berpengaruh positif dan signifikan terhadap variabel dependen Dividend Payout Ratio (DPR).

Kumpulan penelitian sebelumnya menggunakan objek penelitian yang berbeda serta proksi yang berbeda untuk setiap faktor yang mempengaruhi rasio Dividend Payout Ratio (DPR) sebagai variabel dependen. Namun, seluruh penelitian sebelumnya yang disebutkan menunjukkan bahwa variabel independen, baik rasio Return On Assets (ROA) maupun Earning Per Share (EPS) memiliki pengaruh positif dan signifikan terhadap variabel dependen Dividend Payout Ratio (DPR). Berdasarkan hal tersebut, maka peneliti dapat merumuskan bahwa tingkat Return On Assets (ROA) dan Earning Per Share (EPS) mempengaruhi nilai pembagian besaran dividen yang dinilai pada besaran variabel Dividend Payout Ratio (DPR).

Permasalahan penelitian terjadi setelah adanya perbandingan yang tidak sesuai antara teori yang telah dipaparkan dengan laporan keuangan terpublikasi periode 2009-2017 pada objek penelitian di PT. PP London Sumatra Indonesia Tbk.. Ketidaksesuaian terlihat pada variabel independen, yaitu Return On Asset (ROA) dan Earning Per Share (EPS) yang dinilai mempengaruhi tingkat variabel dependen, yaitu Dividend Payout Ratio (DPR). Didasarkan pada latar belakang permasalahan penelitian yang telah secara jelas dan rinci dipaparkan tersebut, maka penelitian ini akan dilakukan dengan judul Pengukuran Dividend Payout Ratio melalui Return On Assets dan Earning Per Share.

\section{METODE PENELITIAN}

Metode deskriptif dengan metode pendekatan kuantitatif dipilih menjadi metode dalam penelitian ini. Metode tersebut akan menguraikan secara sistemastis semua fakta serta hubungan antar variabel dengan menganalisis data yang berupa angka dari laporan keuangan sebagai sumber data utama serta selanjutnya digunakan analisis uji statistik dalam mengolah data. Data penelitian sekunder dipilih untuk penelitian, bukan semata-mata untuk mempermudah penelitian saja, namun juga menitikberatkan pada kredibilitas sumber data tersebut. Data yang digunakan dalam penelitian ini didapat dari sumber laporan keuangan terpublikasi PT. PP London Sumatra Indonesia Tbk. di website www.idx.co.id.

Teknik analisis data yang dipilih pada penelitian ini adalah sebagai berikut: 1) Analisis deskriptif, yaitu teknik analisis data yang dipilih dengan tujuan untuk mendeskripsikan atau menggambarkan objek penelitian dan disajikan dengan sistematis dan faktual, 2) Analisis uji linier berganda, yaitu teknik analisis data yang dipilih dengan tujuan untuk menguji signifikansi pengaruh dari variabel independen, baik $X_{1}$ dan $X_{2}$ secara simultan atau bersama-sama terhadap variabel dependen $Y$. Data penelitian akan melewati analisis uji asumsi klasik terlebih dahulu sebelum dianalisis dan diolah. Analisis uji asumsi klasik yang digunakan pada penelitian ini di antaranya adalah uji normalitas, uji multikolinearitas, uji heteroskedastisitas, serta uji autokorelasi. Rumus persamaan untuk analisis uji linier berganda adalah $Y=$ $a+b_{1} X_{1}+b_{2} X_{2}$.

Keterangan:

$Y=$ Dividend Payout Ratio (DPR), $a=$ Konstanta, $b=$ Koefisien regresi, $X_{1}=$ Return On Assets (ROA), $X_{2}=$ Earning Per Share (EPS). 


\section{HASIL DAN PEMBAHASAN}

\section{Hasil}

Data penelitian terlebih dulu akan melewati analisis uji asumsi klasik sebelum diolah lebih jauh. Setelah dianalisis dengan menggunakan beberapa alat analisis uji asumsi klasik, maka data dalam penelitian ini dapat dikatakan lulus uji normalitas dan dapat disimpulkan bahwa hasil data residual regresi pada penelitian ini berdistribusi normal. Hasil analisis data penelitian juga mengindikasikan bahwa sumber data yang dipilih pada penelitian ini tidak terjadi gejala multikolinieraritas, heteroskedastisitas, maupun autokorelasi.

Selanjutnya, analisis uji linier berganda dalam penelitian ini bertujuan untuk menganalisis serta menguji signifikansi pengaruh dari variabel independen Return On Assets (ROA) dan Earning Per Share (EPS) secara bersama-sama atau simultan terhadap variabel dependen Dividend Payout Ratio (DPR). Berikut tabel perhitungan analisis regresi linier berganda yang telah diolah dengan menggunakan aplikasi SPSS lihat pada tabel 1.

Tabel 1. Analisis Uji Regresi Linier Berganda

\begin{tabular}{|c|c|c|c|c|c|}
\hline \multirow[b]{2}{*}{ Model } & \multicolumn{2}{|c|}{ Unstandardized Coefficients } & \multirow{2}{*}{$\begin{array}{c}\begin{array}{c}\text { Standardized } \\
\text { Coefficients }\end{array} \\
\text { Beta }\end{array}$} & \multirow[b]{2}{*}{$\mathrm{T}$} & \multirow[b]{2}{*}{ Sig. } \\
\hline & B & Std. Error & & & \\
\hline (Constant) & 13,922 & 1,491 & & 9,335 & 000 \\
\hline ROA & 019 & 132 & 049 & 140 & 893 \\
\hline EPS &,- 277 & 112 &,- 860 & $-2,467$ & 049 \\
\hline
\end{tabular}

Hasil tabel di atas menunjukkan nilai $b_{1}$ sebesar $0.019, b_{2}$ sebesar -0.277 , serta nilai konstanta $a$ sebesar 13.922. Berdasarkan hasil perhitungan dari aplikasi SPSS tersebut, maka diperoleh hasil persamaan regresi yang akan diuraikan sebagai berikut.

$$
\begin{gathered}
Y=a+b_{1} X_{1}+b_{2} X_{2} \\
Y=13.922+0.019 X_{1}+(-0.277) X_{2} \\
\text { DPR }=13.922+0.019 \text { ROA }-0.277 \text { EPS }
\end{gathered}
$$

Hasil perhitungan dari persamaan regresi penelitian menunjukkan bahwa konstanta $a$ memiliki nilai 13.922 yang berarti menunjukkan nilai variabel independen $Y$ (Dividend Payout Ratio) sebesar 13.922 pada saat variabel dependen $X_{1}$ (Return On Assets) dan $X_{2}$ (Earning Per Share) sama dengan 0. Nilai koefisien $b_{1}$ menunjukkan nilai positif pada variabel independen $X_{1}$ yaitu Return On Assets (ROA) sebesar 0.019. Hal ini mengasumsikan bahwa setiap peningkatan pada variabel independen Return On Assets (ROA) sebesar 1, maka akan mengakibatkan peningkatan pada variabel dependen Dividend Payout Ratio (DPR) sebesar 0.019 .

Sementara, nilai koefisien $b_{2}$ menunjukkan nilai yang berlawanan dengan variabel independen $X_{1}$, dimana variabel independen $X_{2}$ yaitu Earning Per Share (EPS) memiliki nilai negatif sebesar -0.277 . Hal ini mengasumsikan bahwa setiap peningkatan pada variabel independen Earning Per Share (EPS) sebesar 1, maka akan mengakibatkan penurunan pada variabel dependen Dividend Payout Ratio (DPR) sebesar 0.277 . 
Khazanah Sosial, Vol. 2 No. 3: 205-216

Pengukuran Dividend Payout Ratio Melalui Return on Assets Dan Earning Per Share Listia Andani

\section{Hasil Uji Hipotesis}

Perhitungan analisis uji simultan dengan menggunakan uji $\mathrm{F}$ yang telah dilakukan mendapatkan hasil $\mathrm{F}_{\text {hitung }}$ sebesar 6.361. Hasil ini selanjutnya dibandingkan dengan nilai $\mathrm{F}_{\text {tabel }}$ dengan taraf signifikan sebesar $5 \%$ atau 0.05 yang didapat dari nilai tabel distribusi $\mathrm{F}$ sebesar 5.14. Berdasarkan perbandingan tersebut, maka diperoleh besaran nilai $\mathrm{F}_{\text {hitung }}$ dan nilai $\mathrm{F}_{\text {tabel }}$ yaitu sebesar $6.361>5.14$ dengan besaran nilai signifikansi $0.033<0.05$. Perbandingan tersebut menyimpulkan bahwa hipotesis $\mathrm{H}_{\mathrm{o}}$ ditolak dan $\mathrm{H}_{\mathrm{a}}$ diterima. Hasil tersebut kemudian memberi kesimpulan bahwa secara simultan variabel independen Return On Assets (ROA) dan Earning Per Share (EPS) bersama-sama memiliki pengaruh yang positif dan signifikan terhadap variabel dependen Dividend Payout Ratio (DPR) lihat tabel 2.

Tabel 2. Analisis Uji Regresi Linier Sederhana

\begin{tabular}{|l|c|c|c|c|c|}
\hline \multirow{2}{*}{ Model } & \multicolumn{2}{|c|}{} & \multicolumn{1}{c|}{$\begin{array}{c}\text { Standardized } \\
\text { Coefficients }\end{array}$} & & \\
\cline { 2 - 4 } & \multicolumn{2}{|c|}{ Unstandardized Coefficients } & Beta & $\mathrm{T}$ & Sig. \\
\cline { 2 - 6 } (Constant) & 14,427 & 1,941 & & 7,432 &, 000 \\
ROA &,- 225 &, 115 &,- 595 & $-1,960$ &, 091 \\
\hline (Constant) & 14,063 & 1,020 & & 13,783 &, 000 \\
EPS &,- 266 &, 069 &,- 824 & $-3,843$ &, 006 \\
\hline
\end{tabular}

Hasil analisis uji regresi linier sederhana pada variabel $X_{1}$ menunjukkan hasil bahwa setiap peningkatan dari besaran nilai variabel independen Return On Assets (ROA) sebesar 1 akan mengakibatkan penurunan pada besaran nilai variabel dependen Dividend Payout Ratio (DPR) sebesar 0.225. Dari hasil perhitungan tersebut, maka dapat ditarik kesimpulan bahwa variabel independen Return On Assets (ROA) dan variabel dependen Dividend Payout Ratio (DPR) mengalami hubungan yang negatif. Hal ini selanjutnya mengartikan bahwa jika besaran nilai variabel independen Return On Assets (ROA) semakin tinggi, maka hal itu akan mengakibatkan penurunan besaran nilai pada variabel dependen Dividend Payout Ratio (DPR).

Selanjutnya, hasil analisis uji regresi linier sederhana pada variabel $X_{2}$ menunjukkan hasil bahwa setiap peningkatan nilai variabel independen Earning Per Share (EPS) sebesar 1 akan mengakibatkan penurunan pada nilai variabel dependen Dividend Payout Ratio (DPR) sebesar - 0.266 . Dari hasil tersebut dapat ditarik kesimpulan bahwa telah terjadi hubungan yang negatif pula di antara variabel independen Earning Per Share (EPS) dan variabel dependen Dividend Payout Ratio (DPR). Hal ini selanjutnya mengartikan bahwa jika besaran nilai variabel independen Earning Per Share (EPS) semakin tinggi, maka hal itu akan mengakibatkan penurunan besaran nilai pada variabel dependen Dividend Payout Ratio (DPR).

\section{Analisis Uji Determinasi $\left(\mathbf{R}^{2}\right)$}

Besaran pengaruh variabell Return On Assets (ROA) sebagai $X_{1}$ dan Earning Per Share (EPS) sebagai $X_{2}$ secara bersama-sama atau simultan terhadap variabel Dividend Payout Ratio (DPR) sebagai $Y$ dapat dilihat dari nilai $R$ Square $\left(\mathrm{R}^{2}\right)$. Maka, berikut ini adalah hasil perhitungan analisis uji determinasi $\left(\mathrm{R}^{2}\right)$ yang diolah dengan aplikasi SPSS . 
Khazanah Sosial, Vol. 2 No. 3: 205-216

Pengukuran Dividend Payout Ratio Melalui Return on Assets Dan Earning Per Share Listia Andani

Tabel 3. Analisis Uji Determinasi

\begin{tabular}{|r|c|c|c|c|}
\hline Model & $\mathrm{R}$ & R Square & Adjusted R Square & $\begin{array}{c}\text { Std. Error of the } \\
\text { Estimate }\end{array}$ \\
\hline 1 &, $824^{\mathrm{a}}$ &, 680 &, 573 & 2,17298 \\
\hline
\end{tabular}

Hasil pada tabel 3, dari perhitungan analisis uji determinasi menunjukkan angka dari $R$ Square $\left(\mathrm{R}^{2}\right)$ sebesar 0.680 atau sebesar $68 \%$. Hasil ini mengindikasikan bahwa hubungan antara variabel independen Return On Assets (ROA) dan Earning Per Share (EPS) secara bersama-sama atau simultan terhadap variabel dependen Dividend Payout Ratio (DPR) adalah sebesar 68\%. Sedangkan, untuk 32\% menunjukkan besaran pengaruh variabel-variabel lain yang tidak diteliti dalam penelitian yang mempengaruhi variabel dependen Dividend Payout Ratio (DPR).

Selain uji determinasi, tabel di atas juga menunjukkan hasil uji korelasi antara variabel independen Return On Assets (ROA) maupun Earning Per Share (EPS) terhadap variabel dependen Dividend Payout Ratio (DPR). Hasil uji korelasi menunjukkan angka juga sebesar 0.824 atau sebesar $82.4 \%$. Hasil perhitungan dari penelitian ini mengindikasikan bahwa terdapat korelasi yang sangat kuat terhadap variabel dependen penelitian Dividend Payout Ratio (DPR) dari variabel independen Return On Assets (ROA) dan Earning Per Share (EPS).

\section{Pembahasan}

\section{Pengaruh Return On Assets (ROA) terhadap Dividend Payout Ratio (DPR)}

Return On Assets (ROA) memiliki pengertian sebagai rasio keuangan yang digunakan untuk menakar sejauh mana kemampuan perusahaan dalam menghasilkan laba bersih dari pemanfaatan keseluruhan aset yang dimiliki oleh perusahaan tersebut. Rasio ini menilai sisi efektivitas perusahaan dalam kegiatan operasionalnya sehingga besaran angka pada Return On Assets (ROA) dinilai berbanding lurus dengan produktivitas perusahaan.

Hasil perhitungan data penelitian yang telah dilakukan dengan menggunakan aplikasi SPSS pada variabel Return On Assets (ROA) menunjukkan nilai persamaan regresi linier sederhana sebesar $Y=14.427$ - $0.025 X_{1}$. Hasil persamaan ini memiliki kesimpulan bahwa setiap peningkatan angka pada variabel independen Return On Assets (ROA) sebesar 1 akan berakibat pada penurunan besaran nilai variabel dependen Dividend Payout Ratio (DPR) sebesar -0.225.

Hasil perhitungan analisis uji t pada penelitian ini juga menunjukkan perbandingan antara nilai $t_{\text {hitung }}$ dan nilai $t_{\text {tabel }}$ yaitu sebesar $-1.960<2.3646$ dengan nilai signifikansi sebesar $0.091>0.05$. Perbandingan nilai tersebut menyimpulkan bahwa hipotesis $\mathrm{H}_{a}$ ditolak dan $\mathrm{H}_{0}$ diterima. Maka dari hasil perhitungan penelitian tersebut dapat ditarik kesimpulan bahwa secara parsial variabel independen Return On Assets (ROA) berpengaruh negatif dan tidak signifikan terhadap variabel dependen Dividend Payout Ratio (DPR).

Berdasarkan hasil perhitungan tersebut, maka teori yang menyebutkan bahwa hubungan variabel Return On Assets (ROA) berbanding lurus terhadap variabel Dividend Payout Ratio (DPR) tidaklah sesuai dengan hasil penelitian yang menunjukkan hubungan yang justru berbanding terbalik alias negatif. Hal ini dapat terjadi dikarenakan berbagai faktor yang mempengaruhi besaran pembagian dividen tidak hanya dari sisi profitabilitas, sebagaimana senada dengan teori yang dijadikan landasan dalam penelitian. Dimungkinkan, ada faktor-faktor lain yang lebih dominan mempengaruhi variabel dependen, sehingga 
Khazanah Sosial, Vol. 2 No. 3: 205-216

Pengukuran Dividend Payout Ratio Melalui Return on Assets Dan Earning Per Share Listia Andani

variabel profitabilitas pada $X_{1}$ yang diproksikan dengan Return On Assets (ROA) menjadi tidak berpengaruh signifikan terhadap kebijakan dividen.

Dari hasil perhitungan penelitian yang telah dilakukan, selanjutnya peneliti mampu menarik sebuah kesimpulan bahwa telah terjadi hubungan yang negatif di antara variabel independen Return On Assets (ROA) dan variabel dependen Dividend Payout Ratio (DPR). Hasil tersebut mengindikasikan bahwa jika besaran nilai variabel independen Return On Assets (ROA) semakin tinggi, maka hal tersebut akan berakibat pada penurunan besaran nilai pembagian dividen yang diproksikan oleh nilai variabel dependen Dividend Payout Ratio (DPR).

\section{Pengaruh Earning Per Share (EPS) terhadap Dividend Payout Ratio (DPR)}

Earning Per Share (EPS) memiliki pengertian sebagai rasio keuangan yang digunakan untuk menakar kemampuan perusahaan untuk menghasilkan keuntungan bersih yang dihitung dari setiap lembaran saham yang dimiliki oleh investor atau pemegang saham dan tersebar di pasar (Daulay, 2018; Suhartono et al., 2020). Rasio ini menilai kemampuan perusahaan dalam menjalankan kegiatan operasionalnya sehingga besaran angka pada Earning Per Share (EPS) dinilai berbanding lurus dengan produktivitas perusahaan dan mampu menggambarkan prospek keuntungan yang akan didapat investor.

Hasil perhitungan data penelitian yang telah dilakukan dengan menggunakan aplikasi SPSS pada variabel Earning Per Share (EPS) menunjukkan nilai persamaan regresi linier sederhana sebesar $Y=$ $14.063-0.266 X_{2}$. Hasil persamaan ini memiliki kesimpulan bahwa setiap peningkatan angka pada variabel independen Earning Per Share (EPS) sebesar 1, maka akan berakibat pada penurunan besaran nilai variabel dependen Dividend Payout Ratio (DPR) sebesar -0.266 .

Hasil perhitungan analisis uji t pada penelitian ini juga menunjukkan perbandingan antara nilai $t_{\text {hitung }}$ dan nilai $t_{\text {tabel }}$ yaitu sebesar $-3,843>2.3646$ dengan nilai signifikansi sebesar $0.006<0.05$. Perbandingan nilai tersebut menyimpulkan bahwa hipotesis $\mathrm{H}_{\mathrm{o}}$ ditolak dan $\mathrm{H}_{\mathrm{a}}$ diterima. Maka dari hasil perhitungan penelitian tersebut dapat ditarik kesimpulan bahwa secara parsial variabel independen Earning Per Share (EPS) berpengaruh negatif dan signifikan terhadap variabel dependen Dividend Payout Ratio (DPR).

Berdasarkan hasil perhitungan tersebut, maka teori yang menyebutkan bahwa hubungan variabel Earning Per Share (EPS) berbanding lurus terhadap variabel Dividend Payout Ratio (DPR) tidaklah sesuai dengan hasil penelitian yang menunjukkan hubungan yang justru berbanding terbalik alias negatif. Hal tersebut dapat terjadi diakibatkan beberapa faktor yang mempengaruhi besaran pembagian dividen tidak hanya dari sisi profitabilitas, sebagaimana senada dengan landasan teori yang dijadikan dalam penelitian. Dimungkinkan, ada beberapa faktor lain yang lebih dominan mempengaruhi variabel dependen, sehingga variabel independen pada $X_{2}$ yang diproksikan dengan Earning Per Share (EPS) menjadi berpengaruh negatif meskipun signifikan terhadap kebijakan dividen.

Dari hasil perhitungan penelitian yang telah dilakukan, maka akhirnya peneliti mampu menarik kesimpulan bahwa telah terjadi hubungan yang negatif di antara variabel independen Earning Per Share (EPS) dan variabel dependen Dividend Payout Ratio (DPR). Hasil tersebut mengindikasikan bahwa jika besaran nilai variabel independen Earning Per Share (EPS) semakin tinggi, maka hal tersebut akan berakibat pada penurunan besaran pembagian dividen yang dalam penelitian ini diproksikan oleh nilai variabel dependen Dividend Payout Ratio (DPR). 
Khazanah Sosial, Vol. 2 No. 3: 205-216

Pengukuran Dividend Payout Ratio Melalui Return on Assets Dan Earning Per Share Listia Andani

\section{Pengaruh Return On Assets (ROA) dan Earning Per Share (EPS) terhadap Dividend Payout Ratio (DPR)}

Secara bersama-sama, hasil perhitungan variabel independen Return On Assets (ROA) dan Earning Per Share (EPS) berpengaruh positif serta signifikan terhadap variabel dependen Dividend Payout Ratio (DPR). Hal ini diperkuat dengan hasil nilai korelasi sebesar 0.824 atau $82.4 \%$ yang menunjukkan adanya korelasi yang sangat kuat di antara variabel independen dengan variabel dependen. Serta, hasil nilai $R$ Square $\left(\mathrm{R}^{2}\right)$ sebesar 0.680 atau $68 \%$ yang menunjukkan bahwa hubungan antara variabel independen Return On Assets (ROA) dan Earning Per Share (EPS) terhadap variabel dependen Dividend Payout Ratio (DPR) adalah sebesar 68\%. Sedangkan, untuk angka sebesar 32\% menunjukkan besaran pengaruh variabel-variabel lain yang tidak diteliti dalam penelitian yang mempengaruhi variabel dependen Dividend Payout Ratio (DPR).

Hasil penelitian ini berlawanan dengan penelitian sebelumnya yang dilakukan oleh Janifairus, dkk. (2013), Perpatih (2016), serta Wahyuni \& Hafiz (2018), yang menyatakan bahwa variabel Return On Assets (ROA) berpengaruh positif dan signifikan terhadap variabel Dividend Payout Ratio (DPR). Namun, penelitian ini juga mendukung penelitian sebelumnya, yang dilakukan oleh Indrayati, dkk. (2017) yang menyatakan dalam hasil penelitiannya bahwa variabel Return On Assets (ROA) berpengaruh negatif dan tidak signifikan terhadap Dividend Payout Ratio (DPR).

Hasil penelitian ini juga berlawanan dengan penelitian Pratama (2015) dan Sarmento (2016) yang mendapatkan hasil penelitian bahwa variabel independen Earning Per Share (EPS) berpengaruh positif dan signifikan terhadap variabel dependen Dividend Payout Ratio (DPR), karena hasil penelitian ini menunjukkan variabel Earning Per Share (EPS) berpengaruh negatif dan signifikan terhadap variabel dalam Dividend Payout Ratio (DPR).

Kedua variabel independen dalam penelitian ini menyatakan hasil perhitungan yang negatif atau berkebalikan dari teori yang seharusnya. Hal ini mungkin diakibatkan karena besaran laba perusahaan yang tidak begitu besar, sehingga pembagian dividen tidak bergantung pada besaran laba yang diproksikan pada variabel independen Return On Assets (ROA) maupun Earning Per Share (EPS) dalam penelitian yang pada akhirnya tidak terlalu mempengaruhi hasil akhir pembagian dividen. Besaran pembagian dividen ini sebenarnya dapat dipengaruhi oleh berbagai faktor, di antaranya ada faktor yang mampu membuatnya semakin tinggi, adapula yang membuat besaran dividen semakin rendah.

Faktor yang dimungkinkan akan membuat besaran dividen semakin rendah adalah dari faktor pertumbuhan perusahaan dan juga hutang yang dimiliki perusahaan. Jika perusahaan masih dalam masa pertumbuhan, maka akan dimungkinkan dividen tidak akan dibagikan secara maksimal karena perusahaan akan memilih untuk menahan labanya untuk biaya operasional perusahaan, begitu pula dengan hutang. Jika perusahaan memiliki hutang yang harus segera dibayar atau disegerakan, maka perusahaan akan mengutamakan pembayaran hutang dari keuntungannya dibanding membayar dividen demi kelangsungan operasional perusahaan.

Adapula faktor yang dimungkinkan akan membuat besaran dividen semakin meningkat selain profitabilitas atau keuntungan perusahaan yang digunakan dalam variabel independen dalam penelitian ini, adalah faktor ukuran perusahaan dan posisi kas perusahaan. Perusahaan yang lebih besar memiliki keuntungan dari akses yang lebih luas untuk memperoleh modal. Hal ini dikarenakan semakin besar suatu perusahaan, maka akan semakin terpercaya untuk mengadakan kerjasama oleh berbagai pihak. Sehingga dengan modal yang cukup, maka operasional tercukupi, dan keuntungan yang didapat nantinya dapat dibagikan dalam bentuk dividen. Begitu pula dengan posisi kas perusahaan yang jika semakin besar maka akan menguatkan sisi operasional perusahaan sehingga mampu membagikan dividen decara maksimal. 
Khazanah Sosial, Vol. 2 No. 3: 205-216

Pengukuran Dividend Payout Ratio Melalui Return on Assets Dan Earning Per Share Listia Andani

Hasil perhitungan penelitian ini juga dapat terjadi dikarenakan berbagai faktor lain yang mempengaruhi, terutama dari sisi pemilihan objek penelitian. Perbedaan objek penelitian dapat mempengaruhi hasil penelitian meski dengan variabel yang sama. Begitu pula dengan periode yang dipilih. Semakin banyak dan semakin baru periode yang dipilih dalam penelitian, maka akan memperkuat hasil karena lebih mencerminkan keadaan saat ini. Kondisi perusahaan juga menjadi faktor yang dianggap paling menentukan hasil penelitian karena data yang didapat dari laporan keuangannya. Namun, tidak menutup kemungkinan juga jika ada hal lain seperti faktor eksternal yang berpengaruh terhadap hasil penelitian.

Dari hasil penelitian ini, maka PT. PP London Sumatra Indonesia Tbk. selaku perusahaan yang menjadi objek penelitian yang terpilih diharapkan mampu mengevaluasi kinerja operasionalnya. Hal ini berkaitan dengan segala pertimbangan pada variabel-variabel terkait dan yang dimungkinkan dapat mempengaruhi besaran kebijakan dividen yang digambarkan atau diproksikan pada besaran nilai Dividend Payout Ratio (DPR) yang selanjutnya akan menjadi pertimbangan investor dalam keputusan investasinya.

\section{SIMPULAN}

Berdasarkan analisis perhitungan serta pengolahan data yang secara runut telah dilakukan, maka pada akhirnya peneliti dapat menyimpulkan bahwa variabel independen Return On Assets (ROA) dan Earning Per Share (EPS) secara bersama-sama atau simultan berpengaruh signifikan terhadap variabel dependen Dividend Payout Ratio (DPR). Hal ini dibuktikan dengan perbandingan antara nilai $F_{\text {hitung }}$ dan nilai $\mathrm{F}_{\text {tabel }}$ yaitu sebesar $6.361>5.14$ dengan nilai signifikansi $0.033<0.05$. Hasil ini mengindikasikan bahwa variabel independen penelitian yang berupa rasio profitabilitas secara bersama-sama memang mempengaruhi besaran pembagian dividen perusahaan. Selanjutnya, hasil penelitian juga menyatakan bahwa secara parsial variabel independen Return On Assets (ROA) berpengaruh negatif dan tidak signifikan terhadap variabel dependen Dividend Payout Ratio (DPR) dan juga variabel independen Earning Per Share (EPS) berpengaruh negatif dan signifikan terhadap variabel dependen Dividend Payout Ratio (DPR). Dilihat dari nilai $\mathrm{R}^{2}$, besaran pengaruh variabel independen Return On Assets (ROA) dan Earning Per Share (EPS) terhadap variabel dependen Dividend Payout Ratio (DPR) adalah sebesar 68\%. Sedangkan, untuk 32\% tingkat besaran variabel Dividend Payout Ratio (DPR) dipengaruhi dari variabel lain yang tidak diteliti.

Dari kesimpulan tersebut, maka peneliti juga ingin memberi sedikit saran bagi para peneliti selanjutnya, terutama yang akan menjadikan hasil penelitian ini untuk rujukan atau sumber referensi. Peneliti selanjutnya diharapkan mampu memperluas proksi penelitian dengan menambah variabel independen yang terkait, atau bisa juga menambahkan variabel mediasi atau intervening sebagai perantara yang menghubungkan variabel independen ke variabel dependen. Peneliti selanjutnya juga disarankan mengubah atau memperluas objek penelitian, tidak hanya terpaku pada satu objek perusahaan agar hasil penelitian mewakili banyak sampel dari objek penelitian sehingga hasil penelitian pun akan lebih akurat.

\section{DAFTAR PUSTAKA}

Darsono, \& Ashari. (2005). Pedoman Praktis Memahami Laporan Keuangan. Yogyakarta: Andi Offset. 
Khazanah Sosial, Vol. 2 No. 3: 205-216

Pengukuran Dividend Payout Ratio Melalui Return on Assets Dan Earning Per Share

Listia Andani

Daulay, A. (2018). Pengaruh Return On Assets (ROA), Earning Per Share (EPS) dan Price Earning Ratio (PER) terhadap harga saham perusahaan sub sektor farmasi yang terdaftar di bursa efek Indonesia. IAIN Padangsidimpuan.

Fahmi, I. (2006) . Analisis Investasi dalam Perspektif Ekonomi dan Politik. Bandung: PT. Refika Aditama.

Huda, N. (2018). Ekonomi Makro Islam: Pendekatan Teoritis. Prenada Media.

Huda, N., \& Heykal, M. (2010). Lembaga Keuangan Islam Tinjauan Teoretis dan Praktis. Jakarta: Kencana.

Indrayati, dkk. (2011). Pengaruh Return On Asset (ROA), Management Ownersip, Earning Per Share (EPS), dan Size terhadap Dividend Payout Ratio (DPR) pada Perusahaan Automotive and Allied Product yang Terdaftar di Bursa Efek Indonesia (BEI). Prosiding Seminar Nasional Manajemen dan Ekonomi Bisnis, 1, 387-396.

Janifairus, J. B., dkk. (2013). Pengaruh Return On Asset (ROA), Debt to Equity Ratio (DER), Assets Growth, dan Cash Ratio terhadap Dividend Payout Ratio (DPR). Jurnal Administrasi Bisnis (JAB), 1(1), 161-169.

Kamal, M. B. (2018). Pengaruh Receivable Turn Over Dan Debt To Asset Ratio (DAR) Terhadap Return On Asset (ROA) Pada Perusahaan Pertanian Yang Terdaftar Di Bursa Efek Indonesia (BEI). Jurnal Ilmiah Manajemen dan Bisnis, 17(2).

Parera, D. (2016). Pengaruh Net Profit Margin (NPM), Return On Asset (ROA), dan Debt to Equity Ratio (DER) terhadap Dividend Payout Ratio (DPR) pada Perusahaan yang Tercatat dalam Indeks LQ45 di BEI Periode 2009-2013. Jurnal EMBA, 4(2), 538-548.

Perpatih, Z. ST. (2016). Pengaruh Return On Assets (ROA) dan Debt to Equity Ratio (DER) terhadap Dividend Payout Ratio (DPR) pada Perusahaan Manufaktur Sektor Industri Dasar dan Kimia yang terdaftar di Bursa Efek Indonesia. E-Jurnal Apresiasi Ekonomi, 4(3), 205-211.

Prasetyo, Y. (2017). Hukum Investasi di Pasar Modal Syariah. Bandung: CV. Mitra Syariah Indonesia (MINA).

Pratama, G. N., dkk. (2015). Analisis Pengaruh Asset Growth, Debt to Equity Ratio (DER), Earning Per Share (EPS), dan Reputasi Auditor terhadap Dividend Payout Ratio (DPR) pada Perusahaan yang Tercantum dalam Indeks LQ45 Periode 2009-2013. E-Journal S1 Ak Universitas Pendidikan Ganesha Jurusan Akuntansi S1, 3(1), 1-12.

Riyadi, B. (2017). Profit Analysis with Financial Ratio (Study at Manufacturing in Indonesia Stock Exchange). IOSR Journal of Economics and Finance, 8(5), 39-43.

Santoso, \& Ulfah, R. (2016). Produk Kegiatan Usaha Perbankan Syari'ah dalam Mengembangkan UMKM di Era Masyarakat Ekonomi ASEAN (MEA). Jurnal Penelitian, 10(2).

Sarmento, J. D. C., \& Dana, M. (2016). Pengaruh Return On Equity (ROE), Current Ratio (CR), dan Earning Per Share (EPS) terhadap Kebijakan Dividen pada Perusahaan Keuangan. E-Jurnal Manajemen Unud, 5(7), 4224-4252.

Satria, I. (2016). Pengaruh Manajemen Likuiditas, Manajemen Aset, dan Manajemen Utang terhadap Laba. Jurnal Economia, 12(1), 32-42.

Suardana, I. B. R., dkk. (2018). Influental Factors towards Return On Assets and Profit Change (Study on all BPR in Bali Province). International Journal of Social Sciences and Humanities, 2(1), 105-116.

Suhartono, S., Rahmah, F., Kuspriyono, T., \& Hakim, L. (2020). Pengaruh Rasio Profitabilitas terhadap Earnings Per Share pada Perusahaan Food and Beverage di Bursa Efek Indonesia periode 2016-2018. Jurnal Riset Akuntansi Terpadu, 13(2), 173-190.

Syairozi, M. I., \& Cahya, S. B. (2017). SUKUK AL INTIFAA: INTEGRASI SUKUK DAN WAKAF DALAM MENINGKATKAN PRODUKTIFITAS SEKTOR WAKAF PENDORONG INVESTASI PADA PASAR MODAL SYARIAH. JPIM (Jurnal Penelitian Ilmu Manajemen), 2(2), 12Halaman 
Khazanah Sosial, Vol. 2 No. 3: 205-216

Pengukuran Dividend Payout Ratio Melalui Return on Assets Dan Earning Per Share Listia Andani

Syamsuddin, L. (2011). Manajemen Keuangan Perusahaan: "Konsep Aplikasi dalam Perencanaan, Pengawasan, dan Pengambilan Keputusan, Cet. ke-11. Jakarta: Rajawali Press.

Wahyuni, S. F., \& Hafiz, M. S. (2018). Pengaruh CR, DER, dan ROA terhadap Dividend Payout Ratio (DPR) pada Perusahaan Manufaktur di BEI. Jurnal Ekonomi \& Ekonomi Syariah, 1(2), 25-42. 